\title{
Hyphessobrycon uaiso: new characid fish from the rio Grande, upper rio Paraná basin, Minas Gerais State (Ostariophysi: Characidae), with a brief comment about some types of Hyphessobrycon
}

\author{
Fernando R. Carvalho ${ }^{1,2}$ and Francisco Langeani ${ }^{1}$
}

Hyphessobrycon uaiso is described from the upper rio Paraná basin, rio Grande drainage, Minas Gerais State. The new species differs from its congeners by the short anal fin with 12-17 branched rays, and dorsal fin with ii,7-8 rays. Besides, it can be distinguished by the presence of i,5-6 pelvic fin rays, and by the coloration of the eyes (in life), slightly blue on the lower half and blackish on the upper half. New records of Hyphessobrycon are recognized for the upper rio Paraná basin: H. eilyos Lima \& Moreira, H. guarani Mahnert \& Géry, and H. herbertaxelrodi Géry. The knowledge status about the ichthyofauna from the upper rio Paraná basin and comments about the type material of some species of Hyphessobrycon are briefly discussed.

Hyphessobrycon uaiso é descrito da bacia do alto rio Paraná, drenagem do rio Grande, Minas Gerais. A espécie nova difere de seus congêneres por apresentar nadadeira anal curta, com 12-17 raios ramificados, e nadadeira dorsal com ii,7-8 raios. Além disso, a espécie nova pode ser distinguida pelo número de raios da nadadeira pélvica, com i,5-6 e padrão de colorido do olho (quando vivo), levemente azulado na parte inferior e escurecido na parte superior. Ocorrências novas de Hyphessobrycon são registradas para a bacia do alto rio Paraná: H. eilyos Lima \& Moreira, H. guarani Mahnert \& Géry e H. herbertaxelrodi Géry. O estado da arte da ictiofauna da bacia do alto rio Paraná e comentários sobre alguns exemplares-tipo de Hyphessobrycon são discutidos brevemente.

Key words: Characiformes, Conservation status, Headwaters, New records, Systematics.

\section{Introduction}

Hyphessobrycon Durbin is one of richest genus of Characidae, with approximately 130 valid species, widely distributed on the Neotropical region from Mexico to Argentina (Eschmeyer, 2013). Since the genus was proposed by Durbin (1908) [in Eigenmann, 1908] more than one century ago, few proposals for inter- and intra relationships within Hyphessobrycon were suggested. Current phylogenetic hypotheses to Characidae (Mirande, 2009, 2010 morphological analysis; Oliveira et al., 2011 - molecular analysis), which encompass some species of Hyphessobrycon, failed to include its type species, Hyphessobrycon compressus Meek. Malabarba et al. (2012), in the revalidation of Ectrepopterus Fowler, previously considered a synonym of Hyphessobrycon, analyzed its relationships in the Mirande's (2010) Characidae context, and also included $H$. compressus for the first time in a phylogenetic analysis. The results (Mirande, 2009, 2010; Malabarba, 2012), clearly showed that the genus Hyphessobrycon is not monophyletic and its type species is not close related to some species of Hyphessobrycon [e.g. H. anisitsi (Eigenmann), $H$. bifasciatus Ellis, $H$. elachys Weitzman, $H$. herbertaxelrodi Géry, H. luetkenii (Boulenger)], but to some taxa belonging to the putative 'rosy tetra clade' of Weitzman \& Palmer (1997), such as H. eques (Steindachner), H. pulchripinnis (Ahl), $H$. socolofi (Weitzman), and Hemigrammus unilineatus (Gill). One of the characters supporting the monophyly of this group is the presence of a dark conspicuous spot on the dorsal fin, as suggested by Weitzman \& Palmer (1997). This result partially answered the question raised by Lucena (2003) about the relationships of $H$. compressus with its congeneric species. Despite this initial evidence, there is not a robust proposal for the relationships within the genus Hyphessobrycon, which continues to be diagnosed by the combination of nonexclusive characters first presented by Eigenmann (1917):

${ }^{1}$ UNESP, Universidade Estadual Paulista "Júlio de Mesquita Filho", Instituto de Biociências, Letras e Ciências Exatas, Departamento de Zoologia e Botânica, Laboratório de Ictiologia. Rua Cristóvão Colombo, 2265, Jardim Nazareth, 15054-000 São José do Rio Preto, SP, Brazil.

${ }^{2}$ Programa de Pós-Doutoramento da UNESP. frcarvalho2004@yahoo.com.br 
lateral line incomplete; premaxillary teeth in two series, the inner series with five teeth; second suborbital (= third infraorbital sensu Weitzman, 1962) not in contact with the preopercle ventrally; few maxillary teeth; caudal fin naked, and adipose fin present.

The new species described herein is not a member of the genus Hyphessobrycon sensu stricto (which includes those species related to the type species), but presents the traditional diagnostic characters proposed by Eigenmann $(1917,1918)$. Due to the urgency for the description of new taxa of Neotropical fishes whose habitats are facing increasing and deleterious anthropogenic changes, we herein describe this new species in the traditional concept of the genus Hyphessobrycon until the proposal of the relationships of the genus, an ongoing study by the senior author, is presented.

\section{Material and Methods}

Measurements and counts follow Fink \& Weitzman (1974), Lima \& Moreira (2003), and Carvalho et al. (2010). Measures were made with a caliper rule to the nearest $0.05 \mathrm{~mm}$ on the left side of the specimen whenever possible, and are presented as percents of standard length (SL) or head length (HL). In the description, counts are followed by their frequency in parentheses, and an asterisk indicates the count of the holotype. In the list of paratypes and material examined, the number of all specimens in the lot is followed by the number of those examined and cleared and stained (c\&s) individuals, if any. Counts for vertebrae, supraneurals, gill-rakers on the first branquial arch, branchiostegal rays, procurrent caudal-fin rays, and small dentary teeth were taken from six c\&s specimens prepared according to Taylor \& Van Dyke (1985). Vertebral count includes the four vertebrae in the Weberian apparatus and the fused PU1+U1 of the caudal region as a single element. The pattern of circuli and radii was defined on scales sampled from the region between the lateral line and the insertion of pelvic-fin. Comparisons and data of species not available for examination were taken from the literature. Catalog numbers are followed by the total number of specimens, number of specimens measured and counted in parentheses, and SL range of all specimens of the lot.

Comparative material examined include the most valid species of Hyphessobrycon. For the type material herein analyzed, including some junior synonyms of Hyphessobrycon species and other genera, the names are listed according to the original description; see also Carvalho et al. (2010) for additional examined Characidae taxa.

Institutional abbreviations follow Reis et al. (2003), with addition of Asociación Ictiológica, La Plata, Argentina (AI); Departamento de Zoologia e Botânica, Universidade Estadual Paulista "Júlio de Mesquita Filho", câmpus de São José do Rio Preto, São José do Rio Preto (DZSJRP); Núcleo de Pesquisas em Limnologia, Ictiologia e Aquicultura, Universidade Estadual de Maringá, Maringá (NUP); Departamento de Zoologia, Universidade Federal do Rio Grande do Sul, Porto Alegre (UFRGS), and coleção ictiológica da Fundação Universidade Federal de Rondônia, Porto Velho (UFRO-I).

\section{Hyphessobrycon uaiso, new species Figs. 1-3}

Holotype. DZSJRP 16460, 50.2 mm SL, Brazil, Minas Gerais, Ponte Alta District, municipality of Uberaba, headwaters of rio Uberaba, near BR-262 road, 1940'58.7'S 4740'7.3"W, $1020 \mathrm{~m}$ a.s.1., 8 Sep 2006, F. R. Carvalho, F. Langeani, H. F. Chaves, F. O. Martins \& C. P. Ferreira.

Paratypes. DZSJRP 8731, 272, 17.6-47.4 mm SL, 3 c\&s, 28.549.8 mm SL; LIRP 9298, 15, 27.4-41.5 mm SL; MCP 47520, 20, 26.3-52.9 mm SL; MZUSP 112117, 20, 26.7-46.1 mm SL; UFRGS 17013, 15, 25.7-40.9 mm SL; MNRJ 40368, 20, 27.1-46.6 mm SL; MZUEL 6593, 15, 27.3-41.1 mm SL; NUP 1090, 15, 24.9-45.8 mm SL; INPA 38114, 15, 25.7-47.7 mm SL; same data as holotype; DZSJRP 15804, 105, 25.7-43.6 mm SL, 3 c\&s, 32.5-33.6 mm SL, 6 (ethyl alcohol anhydrous), 25.0-32.3 mm SL, same locality as holotype, 11 Mar 2012, F. R. Carvalho, F. Langeani \& F. O. Martins.

Diagnosis. The new species, Hyphessobrycon uaiso, promptly differs from most congeners [except $H$. amaronensis GarcíaAlzate, Róman-Valencia \& Prada-Pedredos, H. arianae Uj \& Géry, $H$. balbus Myers, $H$. boulengeri (Eigenmann), $H$. brumado Zanata \& Camelier, $H$. coelestinus Myers, $H$. cyanotaenia Zarske \& Géry, $H$. diancistrus Weitzman, $H$. duragenys Ellis, $H$. eilyos Lima \& Moreira, H. elachys Weitzman, $H$. eos Durbin, $H$. frankei Zarske \& Géry, $H$. hamatus Bertaco \& Malabarba, H. isiri Almirón, Casciotta \& Koerber, H. langeanii Lima \& Moreira, H. mavro GarcíaAlzate, Róman-Valencia \& Prada-Pedredos, H. melanostichos Carvalho \& Bertaco, H. metae Eigenmann \& Henn, H. minimus Durbin, H. negodagua Lima \& Gerhard, H. niger GarcíaAlzate, Róman-Valencia \& Prada-Pedredos, H. notidanos Carvalho \& Bertaco, $H$. poecilioides Eigenmann, $H$. reticulatus Ellis, $H$. rutiliflavidus Carvalho, Langeani, Miyazawa \& Troy, H. santae Eigemann, H. sovichthys Schultz, H. stegemanni Géry, H. taurocephalus Ellis, H. tenuis Géry, H. togoi Miquelarena \& Lopez, H. tukunai Géry, H. vinaceus Bertaco, Malabarba \& Dergam, and H. weitzmanorum Lima \& Moreira] by the short anal fin with 12-17 branched rays (mode 14) [vs. less than 11 in H. albolineatum Fernandez-Yépez and more than 18 on the remaining species], and dorsal fin with ii, 7-8 rays [except $H$. arianae Uj \& Géry, $H$. guarani Mahnert \& Géry, H. otrynus Benine \& Lopes, H. procerus Mahnert \& Géry, H. stramineus Durbin, and H. wajat Almirón \& Casciotta] (vs. dorsal fin ii, $8, \mathrm{i}, \mathrm{ii}, 9, \mathrm{ii}, 10$, iii,8, iii,9, or iv,9 rays on the remaining species). From these species with the same range of branched anal-fin and dorsal-fin rays, Hyphessobrycon uaiso differs by the presence of i,5-6 rays on the pelvic-fin (vs. i,7 in $H$. amaronensis, $H$. arianae, $H$. boulengeri, $H$. balbus, $H$. diancistrus, $H$. duragenys, $H$. eos, H. hamatus, $H$. langeanii, H. mavro, H. melanostichos, $H$. minimus, $H$. niger, $H$. otrynus, $H$. poecilioides, $H$. reticulatus, $H$. santae, $H$. sovichthys, $H$. stegemanni, $H$. tenuis, $H$. togoi, and $H$. vinaceus), a conspicuous black humeral spot (vs. humeral spot absent, faint or barely discernible in $H$. brumado, $H$. eilyos, $H$. elachys, $H$. guarani, $H$. procerus, $H$. stramineus, $H$. 


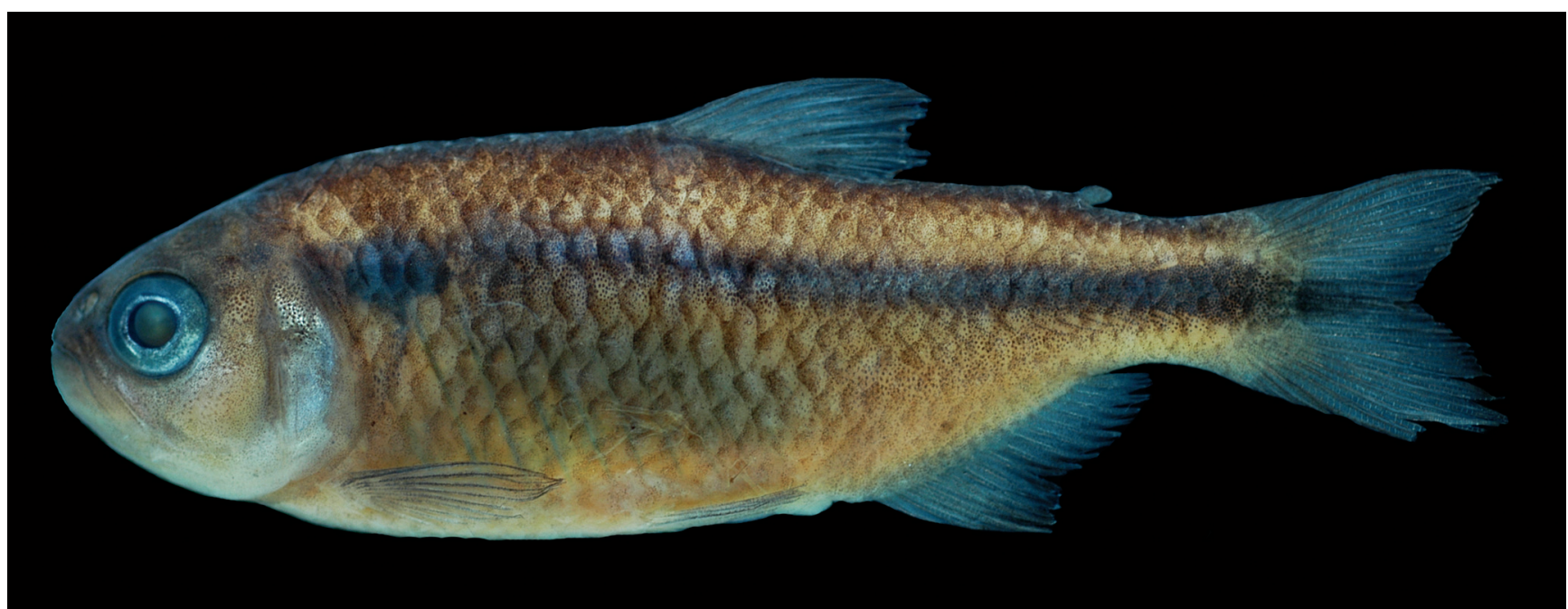

Fig. 1. Hyphessobrycon uaiso, holotype, DZSJRP 16460, $50.2 \mathrm{~mm}$ SL, headwaters of rio Uberaba, near BR-262 road, Ponte Alta District, municipality of Uberaba, Minas Gerais State, Brazil.

tukunai, and $H$. wajat), one or rarely two maxillary teeth with up to seven cusps ( $v s$. two or more maxillary teeth with up to six cusps in $H$. coelestinus, $H$. metae, $H$. notidanos - which can also have up to seven cusps, but never only one teeth in the maxillary, and $H$. rutiliflavidus), and adipose fin present (vs. adipose fin absent in $H$. negodagua and $H$. taurocephalus). Furthermore, Hyphessobrycon uaiso can be distinguished from the congeners by the color pattern of the eyes in life, slightly blue on the lower half and blackish on the upper half, on males and females.

Description. Morphometric data are presented in Table 1. Body compressed, moderately short, greatest body depth at vertical through dorsal-fin origin or straightway after. Dorsal profile of head convex from tip of upper jaw to vertical through anterior nostril; slightly straight or concave from that point to tip of supraoccipital spine. Dorsal profile of body slightly convex from posterior tip of supraoccipital spine to base of last dorsal-fin ray, and straight to adipose-fin origin. Ventral profile of body convex from tip of lower jaw to pelvic-fin origin, straight or slightly convex from that point to anal-fin origin, and straight and/or subtly rounded along anal-fin base. Dorsal and ventral profile of caudal peduncle slightly straight.

Eyes moderate, without distinct adipose eyelid. Jaws equal in size, mouth terminal. Maxilla extending posteriorly surpassing anterior margin of orbit until vertical through crystalline lens anterior margin, slightly curved, aligned approximately at 45 degrees angle relative to longitudinal axis of body. Nostrils close to each other, anterior opening small and circular, posterior one twice in size and slightly reniform or elongate. Nostrils separated by skin flap. Frontals united anteriorly or not, with a triangle-shaped fontanel; parietal fontanel large, extending from epiphyseal bar to supraoccipital spine. Infraorbital series with five or six elements, fourth infraorbital reduced dorsally (triangle-shaped), rectangular, or fusioned with fifth infraorbital. Laterosensorial canal from first to sixth infraorbital close to inner margin of orbital rim. Third infraorbital largest, double size of others (in length and depth), contacting laterosensory canal of preopercle ventrolaterally.

Premaxillary teeth in two rows: outer row with 3(4) or $4 *(48)$, tri- to pentacuspid teeth; inner row with $5 *(53)$ penta- to heptacuspid teeth. Dentary with $5^{*}(53)$ large, penta- to heptacuspid teeth, followed by a series of 4-6 (6) small teeth, conical or tricuspid, abruptly smaller than the anterior largest teeth. Dorsal border of maxilla relatively straight. Maxilla with $1 *(48)$ or 2 (5) penta- to heptacuspid teeth along anteroventral margin (Fig. 2). Central median cusp of all teeth longer than remaining lateral cusps; cusp tips slightly curved inwardly on dentary teeth, and outwardly on premaxillary teeth.

Scales cycloid, with few radii (3-6), relatively small; circuli marked anteriorly and marginally (dorsal and ventral). Lateral line incomplete, extending to vertical through pelvic fin; perforated scales of lateral line 9(15), 10(8), 11*(4), 12(9), 13(6), 14(4), 15(3), 16(1), or 17(3); longitudinal scales series including pored scales 33(8), 34(13), 35*(19), or 36(13); $6 *(48)$ or 6.5(5) scales rows between dorsal-fin origin and lateral line; $5 *(53)$ scale rows between lateral line and pelvic-fin origin. Predorsal scales $10(6), 11 *(24), 12(18)$, or $13(5)$. Scale sheath along anal-fin base $5(12), 6^{*}(21), 7(11), 8(6), 9(4)$, or 10(1) in a single row. Circumpeduncular scales 14(47) or 15(6). Axillary scale small or absent.

Dorsal-fin rays ii,7(3) or $8 *(50)$; first unbranched ray approximately one-half of second one or shorter. Dorsal-fin origin at midbody or posterior to that point, at vertical through anterior third of pelvic fin base. Base of last dorsal-fin ray at vertical through distal tip of pelvic fin, anterior to origin of anal fin. Tip of longest ray of adpressed dorsal fin at vertical through base of first two branched anal-fin rays. First dorsalfin pterygiophore inserting between neural spine of $7^{\text {th }}$ and $8^{\text {th }}$ 


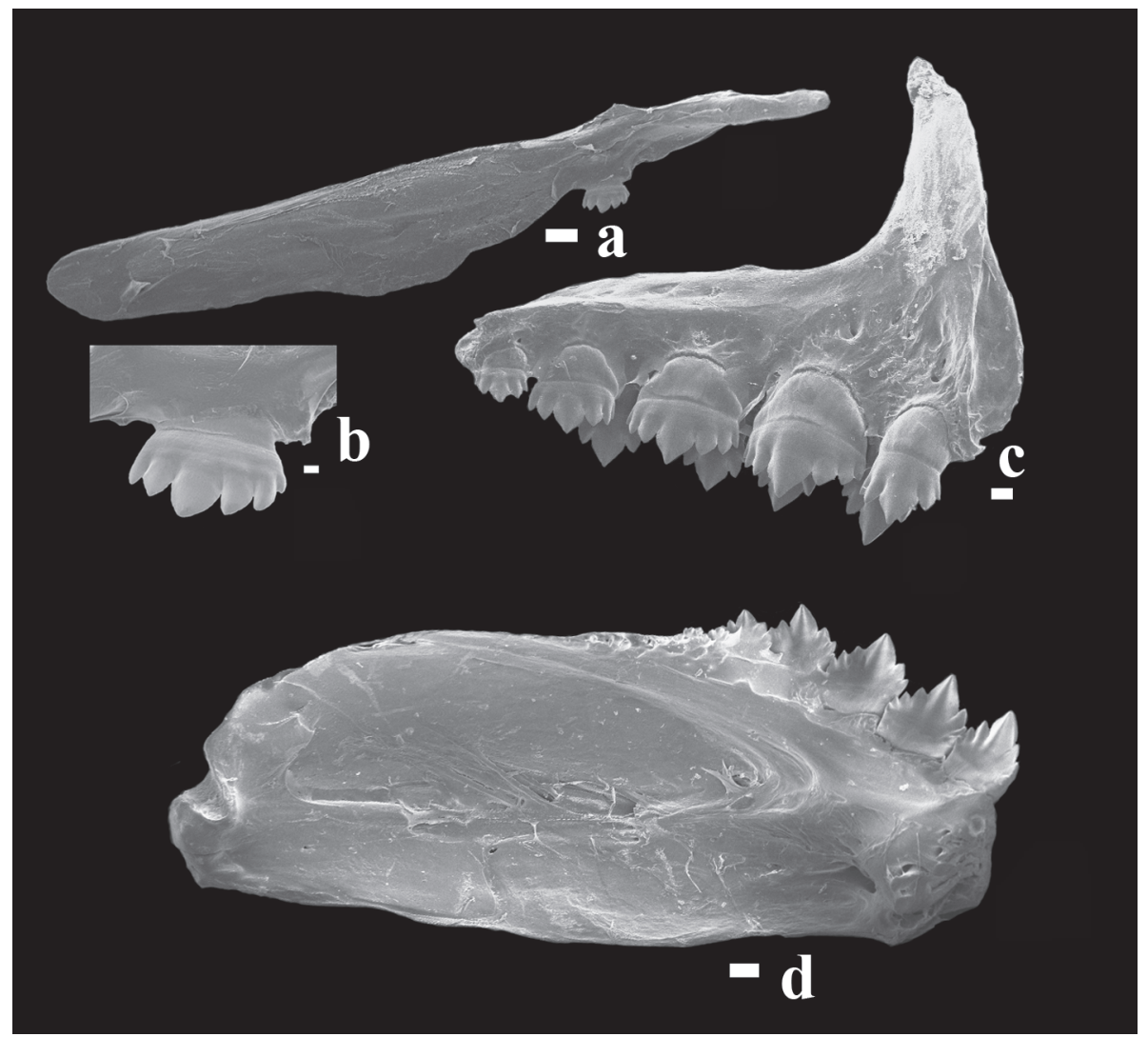

Fig. 2. Hyphessobrycon uaiso, paratype, DZSJRP 8731, $36.4 \mathrm{~mm}$ SL. Scanning electronic micrograph of lower and upper jaws in mesial view, left side: $\mathbf{a}$. maxillary; $\mathbf{b}$. maxillary tooth in detail; $\mathbf{c}$. premaxillary, and $\mathbf{d}$. dentary. Scale bars: $(\mathrm{a}-\mathrm{d})=200 \mu \mathrm{m} ; \mathrm{b}=$ $30 \mu \mathrm{m}$, and $\mathrm{c}=100 \mu \mathrm{m}$.

(6) precaudal vertebra. In some specimens, tips of fin rays deformed (e.g., slightly bent). Adipose fin present, sometimes reduced (just one paratype specimen with adipose fin absent). Pectoral fin with i,9(14), 10*(35), or 11(3) rays, not extending to pelvic fin origin. Pelvic fin with i,5(1) or $6 *(52)$ rays. Pelvicfin origin located anterior or just anterior to vertical through dorsal-fin origin. Tip of longest ray never reaching anal-fin origin. Anal-fin rays iii, 12(2), 13(5), 14(18), 15*(17), 16(9), or 17(2). Anal fin of males and females without bony hooks. Caudal fin forked, lobes slightly rounded, similar in size, with i, $8 / 8, i(3), i, 9 / 7, i(1), i, 9 / 8, i^{*}(46)$, or i, 10/8,i (1) rays. Caudal fin naked, scales restricted to its base. Dorsal procurrent caudalfin rays 10(2), 11(3), or 12(1), and ventral procurrent caudalfin rays $9(3), 10(1), 11(1)$, or 12(1).

Branchiostegal rays 4. First gill arch with 6 gill rakers on epibranchial, 1 between epibranchial and ceratobranchial, 7(2) or 8(4) on ceratobranchial, and 2(5) or 3(1) on hypobranchial. Precaudal vertebrae 16(1) or 17(5) and caudal vertebrae 17(3), 18(2), or 19(1). Supraneurals 5(2) or 6(4), filiform, some with dorsal portion expanded.

Color in alcohol. Overall body color yellowish to brownish. Body scales slightly reticulated, especially on anterior portion of scales. Head dusky to dark brown dorsally. Region of infraorbitals and opercle with small chromatophores, scattered uniformly, except on upper and posterior region with more concentration of spots. Top of head, from lips to supraoccipital process blackish, with high concentration of chromatophores. Humeral spot conspicuous, origin just after opercular opening and extending through five or six transversal scale series, vertically elongated on young specimens (up to $34 \mathrm{~mm} \mathrm{SL}$ ) and approximately vertically rounded on adults (larger than $34 \mathrm{~mm} \mathrm{SL}$ ). When vertically rounded, spot extending through five or six horizontal scale series, above lateral line; on young specimens (up to $32.4 \mathrm{~mm}$ ), humeral spot slender ventral to lateral line. Lateral side of body with scattered melanophores except at abdominal region. Longitudinal stripe dark, one or one-half scale wide, extending from vertical through middle of pectoral fin, passing through end of caudal peduncle end, extending onto proximal one-third of middle caudal-fin rays. Longitudinal stripe more conspicuous posterior to vertical through middle of dorsal-fin base. Caudal peduncle spot merged to longitudinal stripe. Fins darkish, with scattered melanophores on rays and interradial membrane. 

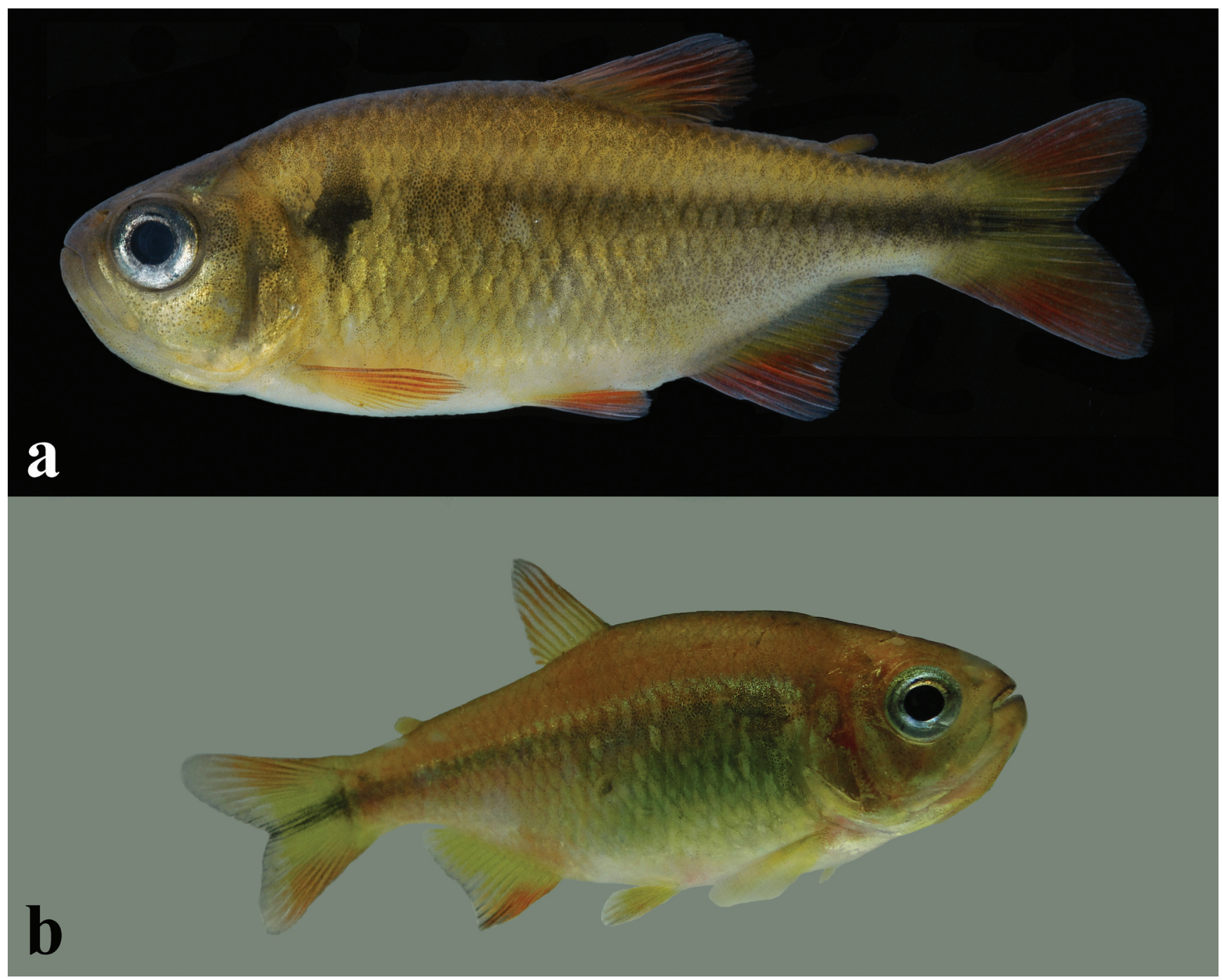

Fig. 3. Hyphessobrycon uaiso: (a) paratype, DZSJRP 15804, specimen just after fixation, $39.3 \mathrm{~mm}$ SL, and (b) specimen in aquarium, $c a$. de $40.0 \mathrm{~mm} \mathrm{SL}$, showing life coloration, not preserved. Photo (b) by Angelo Manzotti.

Color in life. Overall body and head color pattern yellowish, slightly brown (Fig. 3). Pattern of melanophores distribution on head, body and fins similar to that described for specimens in alcohol. Dorsal, caudal, pelvic, and pectoral fins with anterior portion yellowish and posterior reddish. Adipose fin yellowish. Longitudinal stripe more conspicuous along caudal peduncle. Color pattern of eyes composed by slightly blue coloration on lower half and blackish on upper half of iris, on males and females (Fig. 3b).

Sexual dimorphism. The mature males and females of Hyphessobrycon uaiso, confirmed by visual and histological analyses, do not present bony hooks on fins. No difference (morphological or color pattern) was found between males and females. Also, gill glands (Burns \& Weitzman, 1996) were not found macroscopically on first gill arch on both sexes.
Distribution. Hyphessobrycon uaiso is known from rio Uberaba, rio Grande drainage, upper rio Paraná basin (Fig. 4). The upper rio Paraná basin is a well sampled Neotropical basin (Langeani et al., 2007), and even though the upper rio Paraná basin can be considered a well sampled hydrographic system, we are unable to locate any additional samples of the species in the fish collections that hold most material from this river system.

Etymology. The specific name, uaiso, of Portuguese "uai sô", is a common colloquial interjection used by most people living in Minas Gerais State, Brazil, to express surprise, confirmation, awe, amazement, in special those from the "Triângulo Mineiro", region where the new species was found. A name in apposition.

Ecological notes. The headwaters of rio Uberaba are a marshland mainly dominated by Cyperaceae, with some Poaceae, Nymphaeaceae, Melastomataceae, Asteraceae, 
Table 1. Morphometric data for holotype and paratypes of Hyphessobrycon uaiso from the rio Grande drainage, upper rio Paraná basin. $\mathrm{SD}=$ standard deviation; $\mathrm{N}=$ number of specimens (including the holotype).

\begin{tabular}{|c|c|c|c|c|c|}
\hline & Holotype & Paratypes & Mean & SD & $\mathrm{N}$ \\
\hline Standard Length $(\mathrm{mm})$ & 50.2 & $32.4-50.2$ & 38.8 & - & 53 \\
\hline \multicolumn{6}{|c|}{ Percentages of Standard Length } \\
\hline Body depth & 33.0 & $33.0-40.2$ & 36.8 & 1.5 & 53 \\
\hline Head length & 27.6 & $26.7-29.7$ & 28.1 & 0.6 & 53 \\
\hline Head depth & 28.4 & $28.4-34.5$ & 31.6 & 1.2 & 53 \\
\hline Predorsal length & 53.1 & $53.1-58.5$ & 55.9 & 1.1 & 53 \\
\hline Prepelvic length & 52.4 & $50.4-55.7$ & 52.6 & 1.0 & 53 \\
\hline Pelvic fin to anal distance & 18.7 & $17.3-21.5$ & 19.4 & 0.9 & 53 \\
\hline Caudal peduncle depth & 11.4 & 11.3-13.4 & 12.4 & 0.4 & 53 \\
\hline Dorsal-fin base length & 12.8 & $11.1-14.0$ & 12.5 & 0.7 & 53 \\
\hline Anal-fin base length & 20.6 & $16.0-21.5$ & 19.7 & 1.3 & 53 \\
\hline Pectoral-fin length & 19.0 & $17.6-21.6$ & 19.5 & 0.8 & 53 \\
\hline Pelvic-fin length & 13.9 & $12.9-18.4$ & 14.7 & 0.9 & 53 \\
\hline fin length & 23.3 & 21.3 & 23.7 & 1.3 & 48 \\
\hline Anal-fin length & 15.4 & 14.6 & 17.2 & 1.2 & 53 \\
\hline Caudal peduncle length & 15.8 & 13.8 & 16.4 & 1.0 & 53 \\
\hline Dorsal fin to adipose-fin distance & 35.1 & $30.7-35.5$ & 33.7 & 1.2 & 53 \\
\hline Eye to dorsa & 39.8 & $39.5-44.1$ & 41.4 & 1.0 & 53 \\
\hline Dorsal origin to caudal origin & 50.9 & $46.6-52.4$ & 49.7 & 1.1 & 53 \\
\hline \multicolumn{6}{|c|}{ Percentages of head length } \\
\hline Interorbital width & 31.1 & $29.2-35.3$ & 31.5 & 1.1 & 53 \\
\hline Snout length & 23.6 & $21.4-25.5$ & 23.4 & 1.1 & 53 \\
\hline Orbital diameter & 35.4 & $31.6-39.6$ & 37.2 & 1.7 & 53 \\
\hline Upper jaw length & 49.9 & $45.6-51.0$ & 48.7 & 1.5 & 53 \\
\hline
\end{tabular}

and Pteridophyta. When the bottom is not disturbed, the water is clear (Fig. 5). Hyphessobrycon uaiso was found living in schools, occasionally solitary, at average depth of one meter. Schools were mainly found in open areas, devoid of vegetation (Cyperaceae, mainly). Stomach contents of three $c \&$ s specimens contained mostly aquatic insect (apparently Diptera larvae), followed by algae, vegetal matter, Acari, and Thecamoebina. More details about the site of collection of $H$. uaiso are given by Langeani et al. (2007: 120).

Conservation remarks. Recently, Villa-Verde et al. (2012) described Listrura costai and classified this species as vulnerable according to the IUCN categories and criteria for evaluation of threatened species (IUCN, 2001, 2011). Nowadays, it seems important, whenever possible, to evaluate the conservation status of newly described species right at their descriptions. For Hyphessobrycon uaiso, as $L$. costai, the extremely restricted distribution (until now the headwater of rio Uberaba), together with a specificity of habitat, relative proximity of human settlements, the use of surrounding land for agriculture, and human water consumption, defining potential threats to the species, allow to apply the criterion D2 (area of occupation less than 20 $\mathrm{km}^{2}$ ) for the category Vulnerable (VU). Nevertheless, deficiency about population studies or geographical range reductions are not available for the species. Accordingly, it is preferable to consider H. uaiso as data deficient (DD) until more information about its biology and occurrence on the basin is available.

The establishment of conservation measures for the rio Uberaba headwaters is important to conserve its surprisingly diverse restricted ichthyofauna, which include, besides Hyphessobrycon uaiso, another three putative endemic, and so far undescribed taxa: a new Characidae related to Hasemania crenuchoides (of Langeani et al., 2007), a new Crenuchidae, and a possibly undescribed species of Rivulus (Rivulidae).

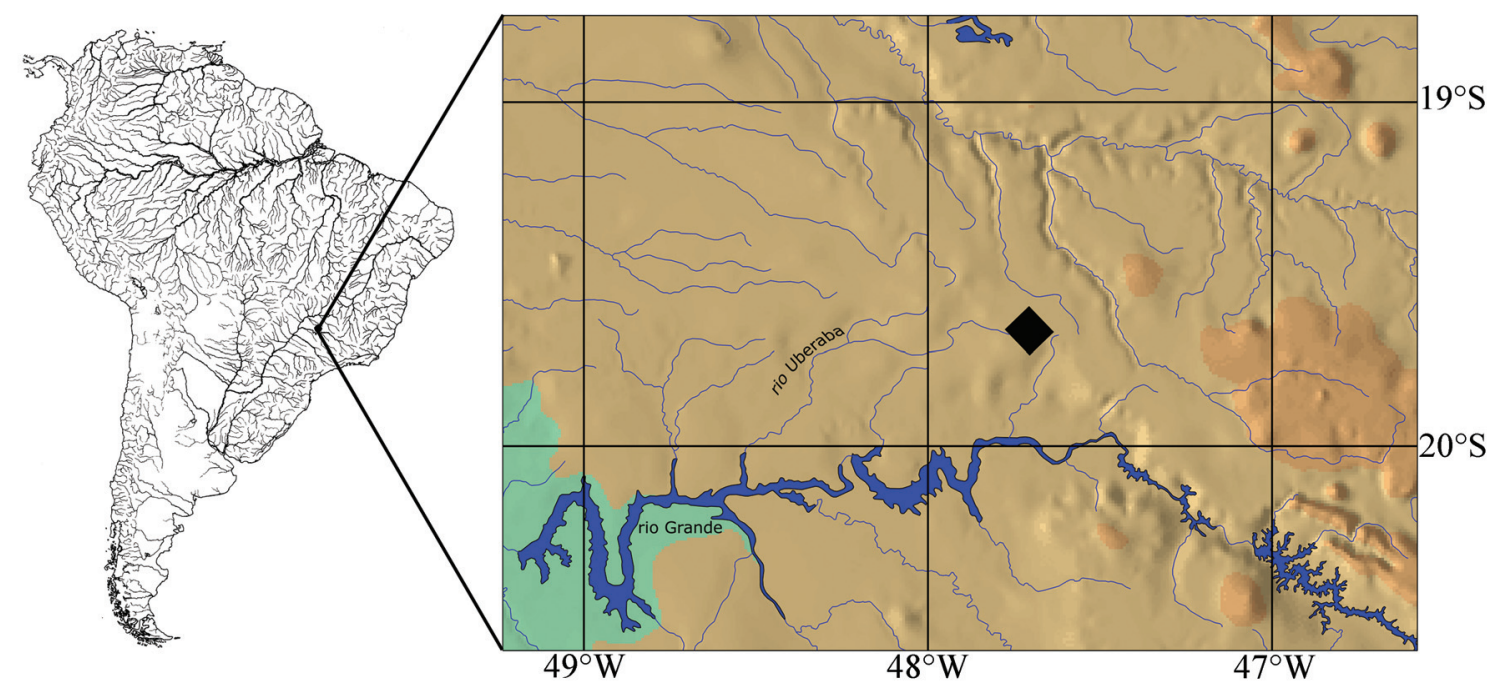

Fig. 4. Distribution map of Hyphessobrycon uaiso (square) in rio Uberaba (detail), rio Grande drainage, upper rio Paraná basin, Brazil. Base map of South America prepared by Marilyn Weitzman. 


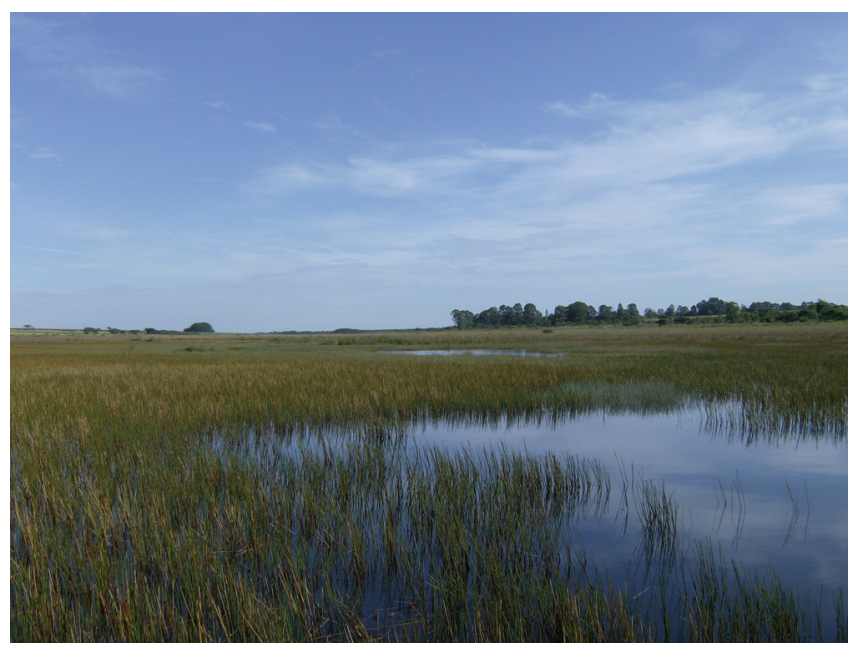

Fig. 5. Type locality of Hyphessobrycon uaiso, Brazil, Minas Gerais State, headwaters of rio Uberaba, near BR-262 road.

\section{Discussion}

Hyphessobrycon is clearly a non-monophyletic genus (Mirande 2009, 2010; Malabarba et al., 2012). The detection of monophyletic groups housed in Hyphessobrycon is expected, however, indicatives of smaller monophyletic units will requires a well-supported analysis of relationships among most of the valid species of Hyphessobrycon, avoiding the numerous generic taxa proposed without autapomorphic characters. This is the justification for the description of this taxon in the Hyphessobrycon sensu Eigenmann (1917). Furthermore, we are in need to describe the components of the Neotropical ichthyofauna rapidly, given the advance of deleterious anthropogenic interference in the aquatic environments.

Some characteristics of Astyanax scabripinnis species complex (e.g., head heavy, reduced number of branched anal-fin rays, presence of one humeral spot, and a dark, midlateral, body stripe extending to the tip of the middle caudal-fin rays), like delimited by Bertaco \& Lucena (2006), also are present in Hyphessobrycon uaiso, but the body depth (mean $36.8 \% \mathrm{SL}$ ) and mainly the lateral line incomplete in all specimens differ the new species from Astyanax scabripinnis species complex (vs. body depth mean 30$33 \%$ of SL and lateral line complete). On the other hand, besides presenting some characters as in Hasemania Ellis (e.g., lateral line incomplete, caudal fin naked), Hyphessobrycon uaiso differs from all Hasemania species by presenting adipose fin ( $v s$. absent in Hasemania, except in some specimens of Hasemania nana, and just one specimen of Hyphessobrycon uaiso) a conspicuous humeral spot ( $v s$. absent in H. hanseni Fowler, H. melanura Ellis, and H. nana Lütken); dorsal fin with ii,8 rays (vs. dorsal fin with ii,9 rays in $H$. maxillaris); humeral spot vertically rounded in superior portion on adults and anal fin with bony hooks on mature males (vs. humeral spot vertically elongated and absence of bony hooks on mature males of $H$. crenuchoides Zarske \& Gery); and by presence of scale sheath along anal-fin (vs. absent in H. kalunga Bertaco \& Carvalho and Hasemania piatan Zanata \& Serra).
The condition of dorsal fin with ii,7-8 rays is uncommon among the species of the genus Hyphessobrycon. It is present only in $H$. arianae, $H$. guarani, $H$. otrynus, $H$. procerus, $H$. stramineus, and $H$. wajat. In fact, some of these species (i.e., $H$. guarani, $H$. procerus, and $H$. wajat) are clearly not Hyphessobrycon, because they also present four teeth in the inner row of the premaxilla. These characters define a group inside the family Characidae first proposed by Malabarba \& Weitzman (2003) as the Clade A, and posteriorly corroborated and named by Mirande $(2009,2010)$ as Stevardiinae. Indeed, Hyphessobrycon procerus seems to be close related to Lepidocharax Ferreira, Menezes \& Quaguio-Grassiotto; also, $H$. guarani and $H$. wajat are probably Stevardiinae members. Furthermore, we agree with Malabarba (1998:205) in considering Hyphessobrycon arianae as junior synonym of 'Cheirodon' stenodon, because all characters examined in the $H$. arianae types (e.g., pseudotympanum, arrangement of teeth in the premaxilla, tricuspid teeth, and color pattern) are also present in 'Cheirodon' stenodon. Hyphessobrycon stramineus, on the other hand, is known by an unique specimen, relatively well preserved (but with superior jaw missing), and according to the analysis of the holotype (MCZ 20772 - by FRC), we concluded that $H$. stramineus may be close related to Hemigrammus ora Zarske, Le Bail \& Géry, based on the dentition (five, tri to pentacuspid, teeth in dentary), color pattern (pale humeral spot, and conspicuous caudal peduncle spot - original description in Ellis in Eigenmann, 1918: 190 and direct observation of holotype), and dorsal fin ii, 8 (see redescription of Hemigrammus ora in Jerep et al., 2011). Hyphessobrycon othrynus is a tipical Hyphessobrycon sensu Eigenmann (1917). Hyphessobrycon arianae and H. procerus, differ from H. uaiso by having tricuspid maxillary teeth ( $v s$. maxillary teeth pentacuspid or with more cuspids).

Some others species such as $H$. cyanotaenia Zarske \& Géry, H. hasemani Fowler, H. isiri Almirón, Casciotta \& Koerber, H. khardinae Zarske, H. pando Hein, H. pytai Géry \& Manhert, may have ii,8-9 dorsal-fin rays, with ii, 9 as the modal condition. Hyphessobrycon uaiso differs from $H$. cyanotaenia, $H$. khardinae, H. pando, and $H$. pytai by the presence of one (rarely two) maxillary tooth (vs. two or more); and from $H$. hasemani and $H$. isiri by i,5-6 pelvic-fin rays (vs. i,7).

Thirteen species of Hyphessobrycon are herein recognized for the upper rio Paraná basin: H. anisitsi, H. balbus, $H$. bifasciatus, $H$. coelestinus, $H$. duragenys, $H$. eilyos (new record), H. eques, H. flammeus Myers, H. guarani (new record), $H$. herbertaxelrodi (new record), $H$. moniliger Moreira, Lima \& Costa (mentioned by Zawadzki et al., 2008: 400), $H$. reticulatus, and $H$. uaiso, new species. Hyphessobrycon uaiso differs from all those species by the dorsal fin with ii, 8 rays ( $v s$. ii,9, except $H$. wajat) and pelvic fin with i,5-6 rays (vs. i,7, except $H$. coelestinus, $H$. eilyos, $H$. guarani, and $H$. flammeus).

Hyphessobrycon uaiso is described from the upper rio Paraná basin, one of the most sampled basins in the Neotropical region. Langeani et al. (2007) registered 316 species from the upper rio Paraná basin, and about 50 additional species were 
listed as new taxa awaiting for description. After five years approximately, $26 \%$ of those 50 new species were described and 30 other species not listed in that paper (including new species or new records) were recorded to the basin. Thus, the current number of species from the upper rio Paraná basin is around 360, including Hyphessobrycon uaiso. This fact reinforces that the upper rio Paraná basin is a substantial restricted geographic component for the ichthyofauna and it shows that each portion of the basin, i.e., a stream or a small river, can have a particular and specific ichthyofauna. This is evidenced by the new species described in the last five years, including $H$. uaiso, most of them with restricted distribution (i.e. one stream/river or in some cases a single collection site). Initiatives to preserve and maintain these areas are important for the Neotropical ichthyic diversity conservation.

Comparative material examined. Astyanax scabripinnis paranae: CAS 22555, holotype, 113.8 mm SL, Brazil, Paraná. Aphyocarax [sic] heteresthes: CAS 76377, 4 syntypes, 14.3-17.7 mm SL, Brazil. Aphyocharax axelrodi: MNRJ 9121, male, holotype, $22.4 \mathrm{~mm}$ SL, Trinidad and Tobago, near Piarco, Trindad B. W.; MNRJ 9122, male, paratype, $19.7 \mathrm{~mm}$ SL; MNRJ 9123, male, paratype, $17.4 \mathrm{~mm} \mathrm{SL}$; MNRJ 9124, male, 18.9 mm SL; MNRJ 9125, male, paratype, $18.8 \mathrm{~mm}$ SL; MNRJ 9126, female, paratype, $20.1 \mathrm{~mm}$ SL; MNRJ 9127, paratype, 18.3 mm SL; MNRJ 9128, female, paratype, 18.0 mm SL; MNRJ 9129, female, paratype, $18.4 \mathrm{~mm}$ SL; MNRJ 9130, female, paratype, $16.5 \mathrm{~mm}$ SL - all lots same data as MNRJ 9121. Cheirodon troemneri: ANSP 70157, holotype, $26.3 \mathrm{~mm} \mathrm{SL}$, an aquarium fish without locality, thought to have been obtained in Brazil. The holotype of Cheirodon troemneri is missing, and the specimen in the bottle of holotype is, indeed, Hemigrammus stictus (Durbin). Chirodon [sic] eques: NMW 59810, 2 syntypes, 23.0-23.3 mm SL, Brazil, Amazonas, Villa Bella [Parintins]; NMW 62693, 6 syntypes, 17.3-22.7 mm SL, Brazil, Pará, Óbidos; NMW 95056, 1 syntype, $18.9 \mathrm{~mm}$ SL, same data as NMW 62693. Dermatocheir catablepta: FMNH 53553, holotype, $14.8 \mathrm{~mm} \mathrm{SL}$, Guyana, above the fall, Tumatumari. Hasemania crenuchoides: DZSJRP 14185, 20, 36.3$78.2 \mathrm{~mm}$ SL, ribeirão da Contagem, REBIO Contagem, rio Maranhão affluent, Tocantins drainage; MZUSP 52732, holotype, male, $64.1 \mathrm{~mm}$ SL, córrego Planaltina, upper rio São Bartolomeu (tributary of rio Corumbá, affluent of rio Paranaíba, La Plata system). Hasemania kalunga: MCP 44289, female, holotype, $53.3 \mathrm{~mm}$ SL, Brazil, Goiás State, Cavalcante, córrego in the road GO-241 between Cavalcante and Minaçu, tributary of rio das Almas, rio Paranã drainage, upper rio Tocantins basin. Hasemania maxillaris: FMNH 54303, holotype, 22.6 mm SL, Brazil, Paraná, Porto União, rio Iguaçu. Hasemania melanura: FMNH 54384, holotype, 27.6 mm SL, Brazil, Paraná, Porto União, rio Iguaçu. Hasemania nambiquara: MCP 38390, holotype, 28.6 mm SL, Brazil, Mato Grosso, Comodoro, rio Doze de Outubro on the highway BR-364 between Comodoro and Vilhena, tributary of rio Juruena, upper rio Tapajós drainage. Hasemania piatan: DZSJRP 11933, 17 of 20 paratypes, 23.234.73.5 mm SL, Brazil, Bahia, municipality of Piatã, córrego das Piabas, south of Piabas farm, tributary of rio de Contas. Hemigrammus anisitsi: CAS 11984, holotype with $30.9 \mathrm{~mm}$ SL and 2 paratypes with 22.2-26.5 $\mathrm{mm}$ SL (in the same bottle), Paraguay, Villa Rica, Paraná basin; CAS 44366, 7 paratypes, 18.8-25.2 mm SL, Paraguay, Estancia La Armonia, Caapucu State?, arroyo Carambey. Hemigrammus boulengeri: CAS 44379, holotype, $30.5 \mathrm{~mm}$ SL, Brazil, Rio Grande do Sul. Hemigrammus compressus: BMNH 1905.12.6.4-5, 2 paratypes, male, 31.5-32.5 mm SL, Mexico, Oaxaca, Obispo; CAS 70114 (ex IU 10798, IU 11126), 5, 26.6-32.0 mm SL, Mexico, Obispo, Veracruz; CAS 70116 (ex IU 10929), 1, $31.6 \mathrm{~mm}$ SL, Mexico, Veracruz, Perez (probably río Tesechocán, tributary of río Papaolapan); FMNH 4641, holotype, male, $31.2 \mathrm{~mm}$ SL, Mexico, Oaxaca, río Papaloapan, El Hule; FMNH 4642, 17 paratypes, 26.6-35.7 mm SL, Mexico, Oaxaca, El Hule, río Papaloapan; FMNH 4662, 11 paratypes, 26.2-31.8 mm SL, 1 c\&s, no length (disjointed and in poor condition), Mexico, Oaxaca, Obispo, río Obispo; FMNH 105930 (ex FMNH 4642), 2 paratypes, 28.8-30.8 mm SL, same data as FMNH 4642; MCZ 29911 (ex IU 11126), 2 paratypes, 29.0-30.3 mm SL, Mexico; MHNG 2181.076, 1 paratype, $29.2 \mathrm{~mm} \mathrm{SL}$, same data as FMNH 4642; USNM 55728, 2 paratypes, missing, Mexico, Obispo. USNM 204387, 3 paratypes, male, 30.0-31.3 mm SL, 1 c\&s paratype, ca. $31.0 \mathrm{~mm}$ SL, México, Oaxaca; El Hule. Hemigrammus inconstans: USNM 34591, holotype, 41.9 mm SL, Brazil, Pará [error, corrected in Eigenmann (1918:199) to Colombia]; USNM 306824, 4 paratypes, 37.2$44.1 \mathrm{~mm}$ SL, same data as USNM 34591. Hemigrammus melasopterus: FMNH 52668, 2 paratypes, 22.6-24.2 mm SL, Paraguay, arroyo Pypucú. Hemigrammus robustulus: ANSP 8037, lectotype, $40.6 \mathrm{~mm}$ SL, Ecuador, Pebas; ANSP 8038-ANSP 8052, 15 paralectotypes, $c a$. 40.0-50.0 mm SL, same data as ANSP 8037. Hemigrammus santae: USNM 55652, holotype with $53.4 \mathrm{~mm}$ SL and paratype with $34.1 \mathrm{~mm}$ SL, Brazil, Minas Gerais, Lagoa Santa. Hyphessobrycon agulha: ANSP 39232, holotype, $32.8 \mathrm{~mm}$ SL, Brazil, rio Madeira about 200 miles east of longitude $62^{\circ} 20^{\prime} \mathrm{W}$; ANSP 39233 to ANSP 39283, 52 paratypes, 14.3$23.6 \mathrm{~mm}$ SL, same data as ANSP 39232. Hyphessobrycon amandae: MZUSP 37637, holotype, 18.9 mm SL, Brazil, Mato Grosso, rio das Mortes, some $100 \mathrm{~km}$ before its confluence with the Braço Maior of the rio Araguaia (the western border of the Ilha do Bananal); MZUSP 37368 , paratype, $16.7 \mathrm{~mm}$ SL, same data as MZUSP 37637. Hyphessobrycon amapaensis: MZUSP 52730, holotype, 30.1 mm SL, Brazil, Amapá, about $45 \mathrm{~km}$ north of Macapá, savannah at the BR-156 of sítio Camaipi to Santa Clara, about 11 kilometers from sítio Camaipi (affluent of rio Preto). Hyphessobrycon arianae: MHNG 2412.079, holotype, 22.5 $\mathrm{mm}$ SL, Paraguay, Departamento Caaguazy, río Guyrau-gua affluent of río Monday at $3 \mathrm{~km}$ E of Juan Frutos. MHNG 2412.080, 30, 19.6-22.8 $\mathrm{mm}$ SL, same data as MHNG 2412.079; MHNG 2412.081, 4 c\&s, 23.1$23.2 \mathrm{~mm}$ SL, same data as MHNG 2412.079. Hyphessobrycon auca: MHNG 2644.023, 4 paratypes, 42.2-52.5 mm SL, Argentina, Corrientes, pond in San Juan Poriahu, Esteros del Iberá. Hyphessobrycon balbus: ANSP 134780, paratype, c\&s, 36.1 mm SL, Brazil, Goyas [Goiás], Planaltina, Lagoa Fervedeira; CAS 51789, holotype, 37.9 mm SL, same data as ANSP 134780; CAS 118069 (ex SU 18069), 9 paratypes, 24.5$45.1 \mathrm{~mm}$ SL, same data as ANSP 134780; MCZ 31570, 2 paratypes, 31.8-40.8 mm SL, same data as ANSP 134780. Hyphessobrycon bentosi: CAS 42682, 3 syntypes, 16.1-27.6 mm SL, Brazil, Pará, Obidos, rio Amazonas basin at Obidos; MCZ 20842, 13 syntypes, 15.7-21.8 mm SL, same data as CAS 42682; USNM 120270, 3 syntypes, 22.3-24.4 $\mathrm{mm}$ SL, same data as CAS 42682. Hyphessobrycon bifasciatus: CAS 51790, 5 paratypes, 21.4-33.0 mm SL, Brazil, Rio de Janeiro, São João da Barra, rio Parayba [rio Paraíba do Sul] drainage; CAS 51791, 5 paratypes, 15.6-19.9 mm SL, Brazil, Rio Grande do Sul, rio Ibicuhy [rio Ibicuí], into rio Uruguay at Cacequy [Cacequi]; FMNH 15041, paratype, $28.5 \mathrm{~mm}$ SL, same data as CAS 51970; FMNH 15042, paratype, 30.5 $\mathrm{mm}$ SL, same data as CAS 51970; FMNH 15043, paratype, $27.9 \mathrm{~mm}$ SL, same data as CAS 51970; FMNH 15044, paratype, 32.4 mm SL, same data as CAS 51970; FMNH 15045, paratype, $28.0 \mathrm{~mm} \mathrm{SL}$, same data as CAS 51970; FMNH 54302, 42 paratypes, 14.9-36.7 mm SL, Brazil, Espírito Santo, Muniz Freire; FMNH 54374, 22 paratypes, 11.7-31.6 mm SL, same data as CAS 51791; FMNH 54404, holotype, 33.5 mm SL, Brazil, Rio de Janeiro, Campos, Rio Parahyba [rio Paraíba do Sul]; FMNH 54405, 28 paratypes, 22.5-35.0 mm SL, same data as CAS 51970 (in 22 Jun 1908); FMNH 96014 (ex FMNH 54404), paratype, $27.6 \mathrm{~mm}$ SL, Brazil, Rio de Janeiro, Campos, 1908. Hyphessobrycon cachimbensis: MNRJ 9196, holotype, 29.5 mm SL, 
Brazil, Pará, rio Cachimbo - Cachimbo - FAB airport, below of small falls; MNRJ 9197, paratype, $19.0 \mathrm{~mm} \mathrm{SL}$, same data as MNRJ 9196; MNRJ 9198, paratype, $24.5 \mathrm{~mm}$ SL, same data as MNRJ 9196. Hyphessobrycon compressus milleri: CAS 70115 (ex IU 11255), holotype, male, $31.3 \mathrm{~mm}$ SL, Guatemala, Los Amates (possibly the swamp 0.5 miles to the East). This type was as 'whereabouts unknown' in Lima et al. (2003). Hyphessobrycon columbianus: MTD F 25497 , holotype, $45.7 \mathrm{~mm}$ SL, Colombia, Darien, small stream about 6 kilometers downstream from Acandi, entry of the río Acandi. MTD F 25498, 1 paratype, $40.9 \mathrm{~mm}$ SL, same data as MTD F 25498. Hyphessobrycon coelestinus: CAS 60476, holotype, $22.8 \mathrm{~mm}$ SL, Brazil, Distrito Federal, lago do rio São Bartholomeu [Bartolomeu] (formerly Lagoa Bonita). Hyphessobrycon copelandi: CAS 42683, 5 syntypes, 15.9-27.4 mm SL, Brazil, Amazonas, rio Solimões at Tabatinga; MCZ 20771, 88 syntypes, 15.4-33.5 mm SL, Brazil, Amazonas, Tabatinga [rio Solimões at Tabatinga (aka Sapurara) and environs]; USNM 120271, 6 syntypes, 14.7-28.4 mm SL, same data as MCZ 20771. Hyphessobrycon diancistrus: MZUSP 13179, 2 paratypes, $26.3 \mathrm{~mm}$ SL, Colombia, State of Vichada, río Vichada, about 50 km west of San José de Ocuné; USNM 216607, holotype, 24.4 mm SL, same data as MZUSP 13179. Hyphessobrycon duragenys: CAS 51792, 2 paratypes, 38.1-55.9 mm SL, Brazil, São Paulo, Mogi das Cruzes, rio Tietê; FMNH 54402, 5 paratypes, 34.4-42.4 mm SL, Brazil, São Paulo, Mogi das Cruzes, rio Tietê [one specimen with $35.7 \mathrm{~mm}$ SL is an Astyanax species ]; FMNH 54403, 8 paratypes, 24.0-31.9 mm SL, Brazil, São Paulo, Jacarehy [Jacareí, rio Paraíba do Sul basin; one specimen with $24.0 \mathrm{~mm}$ SL is Hyphessobrycon aff. luetkenii]. Hyphessobrycon ecuadoriensis: CAS 61602, holotype, $23.2 \mathrm{~mm} \mathrm{SL}$, Ecuador, forest pools near Vinces; CAS 122776 (ex SU 22776), 16 paratypes, 16.5-22.1 mm SL, same data as CAS 32454; FMNH 56601, 83 paratypes, 17.3-24.3 mm SL, same data as CAS 61602; MCZ 30951, 29 paratypes, 15.3-21.1 mm SL, same data as CAS 32454. Hyphessobrycon eilyos: MNRJ 24781, 1 of 5 paratype, $20.7 \mathrm{~mm} \mathrm{SL}$, Brazil, Mato Grosso, municipality of Alto Araguaia, córrego do Rancho (headwaters), swamp near the road, $c a$. $17^{\circ} 16^{\prime}$ 'S 53⒉ $4^{\prime} \mathrm{W}$; MZUSP 75126, holotype, $22.6 \mathrm{~mm}$ SL, Brazil, Mato Grosso, municipality of Alto Araguaia, ribeirão do Sapo, km 464.04 of Ferronorte railroad; NUP 838, 180, 16.6-24.6 mm SL, Brazil, Goiás, Chapadão do Céu/ Baús, Capivara Falls (Parque Nacional das Emas), rio Formoso affluent. Hyphessobrycon elachys: MZUSP 28655, 2 paratypes, 14.0-14.5 mm SL, same data as USNM 232393; USNM 232393, holotype, $15.8 \mathrm{~mm}$ SL, male, Paraguay, Departamento San Pedro, swamp $3 \mathrm{~km}$ northwest of Lima, río Aguaray-Guazu system. Hyphessobrycon eos: CAS 60401, 5 paratypes, 26.6-31.0 mm SL, same data as FMNH 52795; FMNH 7354, 2 paratypes, 16.4-17.2 $\mathrm{mm} \mathrm{SL}$, same data as FMNH 52795; FMNH 52795, holotype, 28.1 mm SL, Guyana, Creek between Potaro Landing \& Kangaruma, lower Potaro River, Essequibo River basin; FMNH 52796, 9 paratypes, 16.7-24.2 mm SL, Guyana, Tukeit; FMNH 52797, 2 paratypes, 24.3-30.7 mm SL, same data as FMNH 52795; FMNH 69689, 5 paratypes, 15.3-16.7 mm SL, Guyana, Lower Potaro River, Tukeit; MCZ 30036, 2 paratypes, 16.4-17.9 mm SL, Guyana, Mazaruni-Potaro, Potaro River at Tukeit Fall; USNM 66195, paratype, $25.6 \mathrm{~mm}$ SL, same data as FMNH 52795; USNM 66196, 2 paratypes, 17.5-18.2 mm SL, Guyana, Tukeit; USNM 165449, paratype, $26.8 \mathrm{~mm} \mathrm{SL}$, same data as FMNH 52795. Hyphessobrycon epicharis: MZUSP 42379, 2 of 55 paratypes, 28.6-31.6 mm SL, Venezuela, Departamento Amazonas, small caño off Caño Urami, just upstream along río Negro from Santa Lucia. Hyphessobrycon erythrostigma: ANSP 70208, holotype, $48.0 \mathrm{~mm}$ SL, Brazil?, aquarium fish without locality. Hyphessobrycon flammeus: USNM 92969, 2 syntypes, 24.1-25.4 mm SL, Brazil, Rio de Janeiro, vicinity Rio de Janeiro. Hyphessobrycon frankei: MHNG 2586.033, 54 paratypes, 23.6$31.6 \mathrm{~mm}$ SL, Peru, tributary for río Negro, Aguaytia, Pampa de Sacramento; MTD F 1770, holotype, 33.0 mm SL, Peru, Departamento de Loreto, brook at Carretera Central, 10 kilometers west of Aguaytia, río Ucayali area. Hyphessobrycon georgetti [sic]: ANSP 112186, 2 paratypes, 13.9$16.5 \mathrm{~mm}$ SL, Brazil, Pará, rio Paru do Oeste, igarape E of Tirio, $6 \mathrm{~km}$ from border of Surinam; ZMA 103269, holotype, $16.3 \mathrm{~mm}$ SL, Surimane, side branch of Sipaliwini River, a swampcreek in Paru savannah. Hyphessobrycon griemi: ZMA 101936a, holotype, $19.0 \mathrm{~mm}$ SL, Brazil, Gojas [probably an error]; ZMA 101936b, 2 paratypes, 23.4-25.8 mm SL, same datas as ZMA 101936a. Hyphessobrycon guarani: MHNG 2366.99, holotype, 29.1 mm SL, Paraguay, Departamento Alto Paraná, río Alto Paraná at Puerto Bertoni, in an oxbox of the river; MZUSP 38399, 2 paratypes, 29.2-30.9 mm SL; USNM 290840, 3 paratypes, 25.8-29.1 mm SL, same data as MHNG 2366.99; NUP 3669, 17, 24.1$32.4 \mathrm{~mm}$ SL, Brazil, Mato Grosso do Sul, Taquaruçu, lagoon of Ventura, rio Ivinhema tributary; NUP 6345, 10, 23.8-27.1 mm SL, Brazil, Paraná, Porto Rico, 'ressaco do Pau Véio' (Porto Rico Island), rio Paraná tributary. Hyphessobrycon hamatus: MCP 34000, holotype, male, $44.5 \mathrm{~mm}$ SL, Brazil, Goiás, Mambaí, córrego Cana Brava, tributary of rio Vermelho, rio Tocantins drainage. Hyphessobrycon haraldschultzi: MNRJ 9207, holotype, 14.3 mm SL, Brazil, Goiás, Ilha do Bananal; MNRJ 9210, 6 paratypes, 14.9-17.7 mm SL, same data as MNRJ 9207. MNRJ 9211, 33 paratypes, 12.3-17.6 mm SL, same data as MNRJ 9207. Hyphessobrycon hasemani: ANSP 39230, holotype, 20.4 mm SL, Brazil, rio Madeira above Falls of Guajara-Mirim [Rondônia]; MCP 41223, 50 of 100, 25.4-31.6 mm SL, 3 c\&s, 28.4-29.7 mm SL, Brazil, Mato Grosso, Pontes e Lacerda, stream affluent rio Galera, $c a .71 \mathrm{~km}$ North of rio Guaporé, on BR-174; UFRGS 12337, 3, 26.4-30.9 mm SL, Brazil, Mato Grosso, Vila Bela da Santíssima Trindade, road MT-199 between Vila Bela and Casalvasco municipalities. Hyphessobrycon heliacus: MZUSP 52891, holotype, male, $25.6 \mathrm{~mm}$ SL, Brazil, Mato Grosso, Cláudia, ribeirão Macuco (= córrego Duas-Bocas), tributary of the rio Teles Pires, rio Tapajós basin, $71.9 \mathrm{~km}$ North from Sinop, at the BR-163 road in direction to Santarém. Hyphessobrycon herbertaxelrodi: USNM 196089, holotype, $31.2 \mathrm{~mm}$ SL, Brazil, Mato Grosso, Coxim, río Paraguay basin, Coxim on the rio Taquary, ca. 1960. DZSJRP 11741, 2, 24.9-26.0 mm SL, Brazil, Goiás, Itajá, ribeirão Grande, farm of Mr. Lázaro; DZSJRP 11813, 4, 16.6- 23.7 mm SL, Mato Grosso do Sul, Cassilândia, córrego Galheiro. Hyphessobrycon hexastichos: MCP 37648, holotype, 55.5 $\mathrm{mm}$ SL, Brazil, Mato Grosso, Comodoro, rio Mutum on road BR-364 to cidade de Vilhena, tributary of rio Juruena, upper rio Tapajós drainage. Hyphessobrycon igneus: MLP 8413 (ex Col. Ict. Mus. La Plata № 23IX-80-7), holotype, $26.7 \mathrm{~mm}$ SL, Argentina, Corrientes, lagoon in front to School No 12, road Bella Vista-San Roque; USNM 256727 (ex Col. Ict. Mus La Plata $\mathrm{N}^{\circ}$ 23-IX-80-8), paratype, $23.8 \mathrm{~mm}$ SL, same data as MLP 8413. Hyphessobrycon iheringi: ANSP 69579, holotype, $32.2 \mathrm{~mm}$ SL, Brazil, Ceará, Fortaleza. Hyphessobrycon isiri: AI 192, 3 of 19 paratypes, 37.8-45.3 mm SL, Argentina, Entre Ríos, río Uruguay basin, arroyo Marmol. Hyphessobrycon itaparicensis: MNRJ 29944, 2, 25.027.6 mm SL, Brazil, Sergipe, Estância, riacho do Macaco (rio Fundo subbasin), rio Fundo tributary, bridge at BR-101. Hyphessobrycon khardinae: UFRO-I 14404, 20 of 36, 22.3-30.4 mm SL, rio Ipixuna, in front of rio Purus. Hyphessobrycon langeanii: MZUSP 75127, holotype, $49.8 \mathrm{~mm}$ SL, Brazil, Mato Grosso, municipality of Alto Araguaia, córrego Mosquito, km 476.3 of Ferronorte railroad; DZSJRP 5467, 5 paratypes, 28.9-34.0 mm, same data as MZUSP 75127. Hyphessobrycon latus: ANSP 69578, holotype, $37.6 \mathrm{~mm}$ SL, Brazil, Ceará, Fortaleza. Hyphessobrycon loweae: MZUSP 45749, 2 paratypes, 22.1-22.3 mm SL, Brazil, Mato Grosso, Lago do Leo, rio Suiazinho drainage, rio Xingu basin. Hyphessobrycon melanostichos: MCP 39510, holotype, female, $36.6 \mathrm{~mm}$ SL, Brazil, Mato Grosso, Comodoro, rio Doze de Outubro on road BR-364 between Comodoro and Vilhena. Hyphessobrycon melasemeion: ANSP 71584, holotype, 40.0 mm SL, lower Amazon? aquarium fish. Hyphessobrycon melazonatus: MCZ 20737, lectotype, 
29.2 mm SL, Brazil, Pará, lagoa do Maximo [Lago Maximo, small lake near Parintins]; MCZ 21069, paralectotype, missing, Brazil, Amazonas, Silva, Lago Saraca [Lago Saraca at Silves]. Hyphessobrycon meridionalis: MLP 8339 (ex Col. Ict. Mus. La Plata No 30-III-77-1), holotype, 44.1 $\mathrm{mm}$ SL, Argentina, Provincia de Buenos Aires, Los Talas, quarry on road Provincial $\mathrm{N}^{\circ} 15,70 \mathrm{~m} \mathrm{~S}$ of Delgado Channel, $30 \mathrm{~m}$ of the road towards the río de la Plata. Hyphessobrycon metae: CAS 61751, holotype, 25.7 $\mathrm{mm}$ SL, Colombia, río Meta at Barrigona, río Orinoco basin. Hyphessobrycon minimus: CAS 61753, 2 paratypes, 14.8-16.1 mm SL, same data as FMNH 52794; FMNH 52794, holotype, $14.0 \mathrm{~mm}$ SL, Guyana, Cane grove corner (sand bank below Tukeit), Potaro River, Essequibo River basin. Hyphessobrycon minor: CAS 61754, paratype, 19.3 mm SL, Guyana, Essequibo River at Konawaruk, 6 Nov 1908; FMNH 52789, holotype, missing, same data as CAS 61754. Hyphessobrycon moniliger: MZUSP 67466, holotype, $26.5 \mathrm{~mm}$ SL, Brazil, Tocantins, Araguaçú, farm Praia Alta 2, Araguaçú to Barreira do Piqui road, $27 \mathrm{~km} \mathrm{~N}$ from Araguaçú, pool behind farm's house, rio Água Fria basin. DZSJRP 9000, 70, 19.3-31.1 mm SL, Brazil, Mato Grosso do Sul, Aparecida do Taboado, córrego Brejo Comprido, Ilha Solteira dam. Hyphessobrycon mutabilis: MZUSP 45292, 5 of 8 paratypes, 19.3-20.7 mm SL, Brazil, Mato Grosso, tributary of rio Sete de Setembro, rio Xingu basin, $107 \mathrm{~km}$ SW of Canarana; MZUSP 45752, 4 paratypes, 25.4-26.6 mm SL, Brazil, Mato Grosso, Buriti palm Cabiseru, rio Suiá-Missú drainage, rio Xingu basin. Hyphessobrycon negodagua: MNRJ 19149, 1 of 5 paratypes, 26.3 mm SL, same data as MZUSP 53983; MZUSP 53983, holotype, male, $26.7 \mathrm{~mm}$ SL, Brazil, Bahia, Iraquara, rio Pratinha at fazenda Pratinha. Hyphessobrycon nicolasi: ILPLA 1808, holotype, female, $49.1 \mathrm{~mm} \mathrm{SL}$, Argentina, Entre Ríos Province, Colón Department, El Pelado stream; ILPLA 1811, 8 paratypes, 37.5-43.6 mm SL, same data as ILPLA 1808. Hyphessobrycon notidanos: MCP 39511, holotype, male, $29.8 \mathrm{~mm}$ SL, Brazil, Mato Grosso, Comodoro, rio Doze de Outubro on road BR-364 between Comodoro and Vilhena. Hyphessobrycon otrynus: USNM 349418, holotype, $30.1 \mathrm{~mm}$ SL, Venezuela, Portuguesa, río Portuguesa drainage, río Las Marias, at Quebrada Seca, approximately 45 min upstream by car from Highway 5, $22 \mathrm{~km}$ NNW Guanare, 28 Feb 1998, J. Armbruster \& O. Leon; LIRP 6040, 7 of 8 paratypes, 22.9-26.3 mm SL, Caño Falcon, río Portuguesa. Hyphessobrycon panamensis: MCZ 20688, 5 syntypes, 20.6$23.5 \mathrm{~mm}$ SL, Panama, Matachin, Boqueron River [all specimens dried, held wrapped on cotton in the bottle]; USNM 120416, 2 syntypes, 25.4$25.7 \mathrm{~mm}$ SL, same data as MCZ20688. Hyphessobrycon parvellus: FMNH 54298, paratype, 14.3 mm SL, ribeirão Azul, lagoon; FMNH 54299, 7 paratypes, 9.3-13.7 mm SL, Brazil, Bahia, Queimadas, rio Itapicuru [parched specimens ]; FMNH 54392, holotype, 22.0 mm SL, Brazil, Bahia, Alagoinhas, rio Catu; FMNH 54393, 3 paratypes, 15.3-16.7 mm SL, same data as FMNH 54392 [one specimen with $16.6 \mathrm{~mm} \mathrm{SL}$ is a Serrapinnus piaba, as annotated by L. R. Malabarba in 18 Dec 1992 in a label into bottle]. FMNH 54394, paratype, $16.3 \mathrm{~mm}$ SL, Brazil; FMNH 54395, paratype, 14.3 mm SL, Brazil, Água Quente. Hyphessobrycon piabinhas: ANSP 69580, holotype, $24.3 \mathrm{~mm}$ SL, Brazil, Ceará, Fortaleza; ANSP 69581, 12 paratypes, 22.4-30.0 mm SL, same data as ANSP 69580; ANSP 69594 - ANSP 69598, 5 paratypes, 13.9-22.7 mm SL, Brazil, Ceará, Rio Salgado, Ico; MHNG 2178.018, 2 paratypes, 14.7-16.3 mm SL, same data as ANSP 69580. Hyphessobrycon poecilioides: FMNH 56290, holotype, $41.2 \mathrm{~mm}$ SL, Colombia, Valle del Cauca, Cali; FMNH 56291, 17 paratypes, 37.9-51.3 mm SL, same data as FMNH 56290; FMNH 75150, 19 paratypes, 32.3-45.6 mm SL, same data as FMNH 56290; USNM 79214, 4 paratypes, 38.4-41.4 mm SL, same data as FMNH 56290. Hyphessobrycon procerus: MZUSP 38400, 2 paratypes, 24.027.8 mm SL, Paraguay, Caaguazu Departament, Guyrau-Gua, a Ltr. Juan m. Frutos; USNM 290841, 1 of 3 paratype, $28.7 \mathrm{~mm} \mathrm{SL}$, same data as MZUSP 38400. Hyphessobrycon pulchripinnis: ZMB 20849, holotype, 25.3 mm SL, Brazil, Amazon River? (aquarium specimens). ZMB 32425, paratype, $28.2 \mathrm{~mm} \mathrm{SL}$, same data as ZMB 20849. Hyphessobrycon pyrrhonotus: MZUSP 45714, holotype, $42.0 \mathrm{~mm}$ SL, Brazil, [Barcelos or Santa Isabel do Rio Negro] rio Erere, a tributary to the rio Negro; USNM 326184, 8 paratypes, 36.6-45.0 mm SL, same data as MZUSP 45714. Hyphessobrycon reticulatus: CAS 57604, 2 paratypes, 16.7$33.6 \mathrm{~mm}$ SL, Brazil, São Paulo, Iguape, rio Ribeira [rio Ribeira de Iguape], fresh water by the sea; FMNH 54308, paratype, $21.4 \mathrm{~mm}$ SL, Brazil, Rio Grande do Sul, Cacequy [Cacequi]; FMNH 54397, holotype, 36.9 mm SL, Brazil, Rio de Janeiro, Campos [Campos dos Goytacazes], rio Parahyba [rio Paraíba do Sul]; FMNH 54398, paratype, 38.0 mm SL, Paraná, Morretes; FMNH 54399, 7 paratypes, 30.6-32.9 mm SL, Brazil, Espírito Santo, Muniz Freire, Itapemirim; FMNH 54400, paratype, 35.4 mm SL, Brazil, São Paulo, Mogy das Cruzes, rio Tietê; FMNH 54401, 6 paratypes, 15.0-35.5 mm SL, same data as CAS 57604; FMNH 54921, paratype, $23.5 \mathrm{~mm}$ SL, Brazil, Minas Gerais, rio Doce. Hyphessobrycon rosaceus: CAS 61755, 4 paratypes, 16.4-29.8 mm SL, Guyana, Essequibo River at Gluck Island; FMNH 52791, holotype, 28.6 mm SL, Guyana, Gluck Island; FMNH 52792, 5 paratypes, 18.1$34.1 \mathrm{~mm}$ SL, same data as FMNH 52792; FMNH 52793, paratype, 28.4 mm SL, Guyana, Rockstone, 1908; FMNH 69534, 2 paratypes, 13.4-15.1 mm SL, same data as CAS 61755; FMNH 7352, 2 paratypes, 15.9-17.4 mm SL, same data as CAS 61755; MCZ 30038, 2 paratypes, 16.8-17.8 mm SL, Guyana, EDemerara-WC Berbice, tributary of Essequibo River on Gluck Island, across from Rockstone, Essequibo drainage; SU 21919, 2 paratypes, 16.0-16.9 mm SL, same data as FMNH 52791; USNM 66194, paratype, $16.2 \mathrm{~mm}$ SL, Guyana, Gluck Island. Hyphessobrycon rubrostigma: ZMA 101.935A, holotype, $26.5 \mathrm{~mm}$ SL, Colombia. ZMA 101.935B, 6 paratypes, 22.7-36.8 mm SL, Colombia. Hyphessobrycon rutiliflavidus: DZSJRP 7444, holotype, female, 50.7 $\mathrm{mm}$ SL, Brazil, Mato Grosso, Cuiabá, córrego Pipa, rio Paraguai drainage, next to Serra de São Vicente. Hyphessobrycon saizi: USNM 198647, holotype, $22.0 \mathrm{~mm}$ SL, Colombia, río Manacacias into upper río Meta, at Restrepo, ca. 200 miles $(320 \mathrm{~km}) \mathrm{E}$ of Bogota. Hyphessobrycon savagei: ANSP 164253, 30 of 100, 27.5-32.6 mm SL, 2 c\&s, 29.2-29.3 $\mathrm{mm}$ SL Costa Rica, Puntarenas Providence, culvert pool ar Inter American Highway, ca. $20 \mathrm{~km} \mathrm{~S}$ of Palmar Norte. Hyphessobrycon schauenseei: ANSP 90878, holotype, 23.2 mm SL, Brazil, Pará, rio Inhangapi; ANSP 90879, 3 paratypes, 20.4-21.7 mm SL, same data as ANSP 90878. Hyphessobrycon scholzei: ZMB 20798, lectotype, 30.9 mm SL, Brazil, Pará, rio Amazon at Pará. ZMB 32430, paralectotype, 29.0 mm SL, same data as ZMB 20798. Hyphessobrycon scutulatus: MCP 33333, holotype, male, $35.1 \mathrm{~mm}$ SL, Brazil, Mato Grosso, rio Kaiapá, MT-320 road, about $5 \mathrm{~km}$ from Nova Canaã do Norte, rio Teles Pires drainage, rio Tapajós system. Hyphessobrycon serpae: CAS 42684 (ex IU 12652), 5 syntypes, 21.0-23.0 mm SL, Brazil, Amazonas, Serpa [rio Amazonas at Itacoatiara]; MCZ 20985, 33 syntypes, 20.5-23.5 mm SL, same data as CAS 42684; USNM 120269, 6 syntypes, 20.1-23.1 mm SL, same data as CAS 42684. Hyphessobrycon socolofi: MZUSP 13181, holotype, male, $38.6 \mathrm{~mm}$ SL, Brazil, Amazonas, rio Negro, Barcelos; USNM216612, 5 paratypes, 30.5-39.2 mm SL, same data as MZUSP 13181. Hyphessobrycon sovichthys: MCZ 37239, 5 paratypes, 26.2-28.7 mm SL, Venezuela, Zulia, río Apon, ca. $35 \mathrm{~km}$ by road S of Rosario. USNM 121534, holotype, $26.6 \mathrm{~mm}$ SL, Venezuela, Cienago del Guanavana, about $10 \mathrm{~km}$ N of Sinamaica; USNM 121536, 14 paratypes, 21.6-30.2 mm SL, Venezuela, río Negro below mouth of río Yasa. Hyphessobrycon stegemanni: USNM 195942, holotype, $31.1 \mathrm{~mm}$ SL, Brazil, savannahs of northeastern Brazil, between the lower rio Tocantins and the rio Capim. Hyphessobrycon stramineus: MCZ 20772, holotype, 27.6 mm SL, Brazil, Amazonas, Tabatinga [rio Solimões at Tabatinga (aka Sapurara) and environs]. Hyphessobrycon takasei: USNM 198138, holotype, female?, 30.0 mm SL, Brazil, Amapá, Serra do Navio above Macapá, lower Amazon basin. Hyphessobrycon taurocephalus: CAS 22778 (ex IU 13277), 5 
paratypes, 30.0-43.3 mm SL, same data as FMNH 54389 (but with wet label of locality Serrinba, Paraná, probably an error); FMNH 15091, paratype, 41.7 mm SL, Brazil, Paraná, Serrinha, Paraná; FMNH 15092, paratype, $32.3 \mathrm{~mm}$ SL, same data as FMNH 15091; FMNH 15093, paratype, $33.4 \mathrm{~mm}$ SL, same data as FMNH 15091; FMNH 54389, holotype, $43.3 \mathrm{~mm}$ SL, Brazil, Paraná, into rio Paraná at Serrinha, Paraná: either river or nearby creek, [rio Iguaçu basin]; FMNH 54391, 22 paratypes, 22.6-34.9 mm SL, Brazil, Porto União, rio Iguassu [Iguaçu]. Hyphessobrycon tenuis: ANSP 139708, paratype, $22.8 \mathrm{~mm}$ SL, Peru, Peruvian Amazon, small brook connecting 'Zapote Cocha' with Caño Yarina at edge of río Pacaya, affluent of Canal de Puinahua (arm of the lower río Ucayali). Hyphessobrycon togoi: ILPLA 1704, holotype, 59.5 $\mathrm{mm}$ SL, Argentina, Buenos Aires Province, Chascomús lagoon; ILPLA 1705, 4 paratypes, 62.5-69.8 mm SL, same data as holotype; ILPLA 1232, paratype, $65.2 \mathrm{~mm}$ SL, Argentina, Buenos Aires Providence, Lobos lagoon. Hyphessobrycon tortuguerae: ANSP 80986, 2 paratypes, 25.226.6 mm SL, Costa Rica, Tortuguero River and lagoon at Tortuguero, 2 miles from inlet; ANSP 80987, paratype c\&s, $26.4 \mathrm{~mm} \mathrm{SL}$, same data as ANSP 80986. Hyphessobrycon tropis: USNM 198639, holotype, 21.1 mm SL, Brazil, Amazonas, near Tapurucuara, upper rio Negro. Hyphessobrycon vilmae: MHNG 2229.004, holotype, $27.3 \mathrm{~mm}$ SL, Brazil, Mato Grosso, small stream in the road Cuiabá to upper rio Arinos; USNM 198137, paratype, $27.2 \mathrm{~mm}$ SL, same data as MHNG 2229.004. Hyphessobrycon vinaceus: MCP 40916, $56.5 \mathrm{~mm}$ SL, holotype, male, Brazil, Minas Gerais, São João do Paraíso, rio São João, tributary of the upper rio Pardo. Hyphessobrycon wajat: MLP 7853, 10 paratypes, 24.8-25.0 mm SL, Argentina, Chaco Province, Resistencia city, río Negro; MLP 7875, 10 paratypes, 21.6-26.8 mm SL, Argentina, Chaco Province, Resistencia city, Laguna Blanca; MLP 9321, holotype, 27.2 mm SL, Argentina, Corrientes Province, Laguna Brava; MLP 9322, 5 paratypes, 28.2-30.2 mm SL, Argentina, Corrientes Province, Laguna Iberá. Hyphessobrycon weitzmanorum: MNRJ 24782, 1 of 5 paratype, $20.4 \mathrm{~mm}$ SL, Brazil, Mato Grosso, municipality of Alto Araguaia, córrego Gordura, km 491.4 of Ferronorte railroad; MZUSP 73315, holotype, male, Brazil, Mato Grosso, municipality of Alto Araguaia, córrego Mosquito, km 476.3 of Ferronorte railroad. Hyphessobrycon werneri: MZUSP 42365, holotype, 32.2 mm SL, Brazil, Pará, rio Guamá basin, forest stream between Santa Maria do Pará and São Miguel de Guamá, about $120 \mathrm{~km}$ from Belém (Pará), on highway BR-010. Megalamphodus ecuadorensis: IU 13628, missing. [The holotype of M. ecuadorensis never was registered in CAS (David Catania, pers. comm.). The characters of M. ecuadorensis (= Hyphessobrycon ecuadorensis ) are the same of Hyphessobrycon ecuadoriensis, therefore, H. ecuadorensis can be a junior synonym of $H$. ecuadoriensis]. Megalamphodus megalopterus: CAS 78887, paratype, $27.1 \mathrm{~mm}$ SL, same data as FMNH 57823; FMNH 57823, holotype, $26.9 \mathrm{~mm}$ SL, Brazil, Mato Grosso, creek six miles back of San Luiz de Caceres [Cáceres]; FMNH 57824, 2 paratypes, 18.2-28.3 mm SL, same data as FMNH 57823. Megalamphodus micropterus: CAS 98918, 6 paratypes, 21.3-23.7 mm SL, Brazil, Pirapora, rio São Francisco basin; FMNH 57916, holotype, 23.5 mm SL, Brazil, rio São Francisco, Lagoa do Porto; FMNH 57917, 14 paratypes, 17.4-24.1 mm SL, same data as FMNH 57917; FMNH 57918, 9 paratypes, Brazil, Santa Rita, rio São Francisco; FMNH 57920, paratype, 20.8 mm SL, Brazil, rio Salitre. Megalamphodus roseus: ANSP 112496, 2 paratypes, 13.7-14.5 mm SL, French Guiana, upper Maroni, stream near Gaa Kaba, creek from le. Tampoc; ANSP 139704, paratype, $15.2 \mathrm{~mm}$ SL, French Guiana, stream near Gaa Kaba, Maroni. Megalamphodus sweglesi: USNM 196090, holotype, 29.9 mm SL, Colombia, upper Amazon, surroundings of 'Leticia' (Columbian District). Megalamphodus (Ectrepopterus) uruguayensis: ANSP 70331, holotype, $29.6 \mathrm{~mm}$ SL, Uruguay. Pristicharax hanseni: ANSP 72104, holotype, 31.4 mm SL, Goiaz [Goiás].
Pseudopristella simulata: ANSP 112203, paratype, $31.8 \mathrm{~mm}$ SL, French Guiana, River Kourou at Kourou (coast); ANSP 139703, 4 paratypes, 15.5-26.2 mm SL, French Guiana, stream near Sinnamary (coast); SMF 4786, holotype, $31.5 \mathrm{~mm}$ SL, same data as ANSP 112203. Tetragonopterus callistus: BMNH 1900.4.14.6368, 6 syntypes, 17.3-27.0 mm SL, Brazil, Matto Grosso [Mato Grosso], Carandasinho; MSNG 37718, 2 syntypes, 25.9-28.6 mm SL, same data as 1900.4.14.63-68. MZUT 1365, 11 syntypes, 20.4$27.7 \mathrm{~mm}$ SL, same data as 1900.4.14.63-68. Tetragonopterus heterorhabdus: CAS 44415, 9 syntypes, 9.6-20.0 mm SL; CAS 102174(ex SU 2174), syntype, 58.6 mm SL, Brazil, Pará [specimen is an Astyanax species, probably Astyanax cf. anterior. The specimen is damaged between dorsal fin end and adipose fin origin. A note in label explains this: "bottle broken during earthquake]. Tetragonopterus luetkenii: BMNH 1885.2.3.78-80, 3 syntypes, 34.235.5 mm SL, Brazil, Rio Grande do Sul, San Lorenzo [São Lourenço] [one specimen with $34.4 \mathrm{~mm} \mathrm{SL}$ is a Hyphessobrycon igneus]; BMNH 1886.15.35-38, 4 syntypes, 55.6-63.0 mm SL, same data as BMNH 1885.2.3.78-80. Tetragonopterus nanus: USNM 44958, 4 syntypes, 14.3-18.2 mm SL, Brazil, [Minas Gerais], lagoa Santa.

\section{Acknowledgments}

We are grateful to Fernanda Martins (IBILCE/UNESP), Cristiane P. Ferreira (UFPA), and Henrique F. Chaves for their help in the field work; Jaquelini Zeni (IBILCE/UNESP) for stomach content analysis; Angelo R. Manzotti (IBILCE/UNESP) for the photo of alive specimen; Fernando Jerep (USNM) for suggestions to improve the English. For museum and technical support and/or loan of material we thank Adriana Almirón (AI), Barbara Brown, Scott Schaeffer (AMNH), John Lundberg, Mark Sabaj Pérez, Kyle Luckenbill(ANSP), James Maclaine(BMNH), David Catania, Jon Fong, Tomio Iwamoto (CAS), John Friel (CU), Mary Anne Rogers, Kevin Swagel, Philip Willink, Susan Mochel (FMNH), Vinicius Bertaco (FZB/RS), Mike Retzer (INHS), Lúcia Rapp Py-Daniel, Marcelo Rocha, Renildo Oliveira, Túlio Teixeira (INPA), Lucila Protogino (ILPLA), Claudio Oliveira, Ricardo Benine (LBP), Gustavo Chiaramonte, Ricardo Ferriz (MACN), Flávio Bockmann, Thiago Pereira, Ricardo Castro (LIRP), Carlos Lucena, Margarete Lucena, Roberto Reis, Barbara Calegari(MCP), Axel Zarske(MTD F), Karsten Hartel (MCZ), Sonia Fisch-Muller, Raphael Covain (MHNG), Amalia Miquelarena, Hugo López, Diego Nadalin(MLP), Paulo Buckup, Marcelo Britto (MNRJ), Wolmar Wosiaki (MPEG), Giuliano Doria(MSNG), Osvaldo Oyakawa, José Birindelli, Manoela Marinho, José Lima de Figueiredo (MZUSP), Franco Andreone (MZUT), Wellendorf Helmut(NMW), Carla Pavanelli, Weferson Graça (NUP), Erling Holm, Hernán López-Fernández, Richard Winterbottom (ROM), Ronald de Ruiter (SMF and ZMA), Luiz Malabarba, Juliana Wingert, Juliano Ferrer(UFRGS), Richard Vari, Jerry Finan, Jeffrey Clayton, Sandra Raredon, Fernando Jerep (USNM), Doug Nelson, Willian Fink(UMMZ), Flávio Lima(ZUECPIS). FRC is supported by a postdoctoral fellowship from FAPESP (Fundação de Amparo à Pesquisa do Estado de São Paulo) (procs. 2011/11422-8 and 2012/03404-2.) and FL is supported by CNPq (Conselho Nacional de Desenvolvimento Científico e Tecnológico) (Proc. 305946/2011-0). Field work supported by FAPESP (proc. 
2011/11422-8). Types analysis was possible due to scholarship program for Sandwich Ph.D. of CNPq for FRC (proc. 201513/20099), under supervision of Richard P. Vari, at Smithsonian Institution, National Museum of Natural History, Washington, D.C. Collecting permits were provided by Instituto Brasileiro do Meio Ambiente e dos Recursos Naturais Renováveis - IBAMA ( $\mathrm{n}^{\circ} 009 / 2003$ and $\mathrm{n}^{\circ}$ 150/2005-DIFAP/IBAMAin 2006 and \# 16984-1, IBAMA/ICMBio in 2012).

\section{Literature Cited}

Bertaco, V. A. \& C. A. S. de Lucena. 2006. Two new species of Astyanax (Ostariophysi: Characiformes: Characidae) from eastern Brazil, with a synopsis of the Astyanax scabripinnis species complex. Neotropical Ichthyology, 4: 53-60.

Burns, J. R. \& S. H. Weitzman. 1996. Novel gill-derived gland in the male swordtail characin, Corynopoma riisei (Teleostei: Characidae: Glandulocaudinae). Copeia, 1996: 627-633.

Carvalho, F. R., V. A. Bertaco \& F. C. Jerep. 2010. Hemigrammus tocantinsi: a new species from the upper rio Tocantins basin, central Brazil (Characiformes: Characidae). Neotropical Ichthyology, 8: 247-254.

Eigenmann, C. H. 1908. Preliminary descriptions of new genera and species of tetragonopterid characins. (Zoölogical Results of the Thayer Brazilian Expedition). Bulletin of the Museum of Comparative Zoology, 52: 91-106.

Eigenmann, C. H. 1917. The American Characidae - I. Memories of the Museum of Comparative Zoölogy, 43: 1-102.

Eigenmann, C. H. 1918. The American Characidae - II. Memories of the Museum of Comparative Zoölogy, 43: 103-208.

Eschmeyer, W. N. (Ed.). 2013. Catalog of Fishes. California Academy of Sciences. Electronic version updated 11 February 2013. Available from: http://research.calacademy.org/research/ ichthyology/catalog/fishcatmain.asp (04 March 2013).

Fink, W. L. \& S. H. Weitzman. 1974. The so-called Cheirodontin fishes of Central America with descriptions of two new species (Pisces: Characidae). Smithsonian Contributions to Zoology, 172: 1-46.

IUCN - International Union for Conservation of Nature. 2001. IUCN Red List Categories and Criteria: Version 3.1. IUCN Species Survival Commission. IUCN, Gland, Switzerland and Cambridge, United Kingdom.

IUCN - International Union for Conservation of Nature. Standards and Petitions Subcommittee. 2011. Guidelines for Using the IUCN Red List Categories and Criteria. Version 9.0. Prepared by the Standards and Petitions Subcommittee, 87p. Available from: http://www.iucnredlist.org/documents/ RedListGuidelines.pdf (November, 2012).

Jerep, F. C., F. R. Carvalho \& V. A. Bertaco. 2011. Geographic distribution of Hemigrammus ora (Ostariophysi: Characiformes: Characidae) in the Amazon basin, Brazil. Zoologia, 28: 545-550.

Langeani, F., R. M. C. Castro, O. T. Oyakawa, O. A. Shibatta, C. S. Pavanelli \& L. Casatti. 2007. Diversidade da ictiofauna do Alto Rio Paraná: composição atual e perspectivas futuras. Biota Neotropica, 7: 1-17.

Lima, F. C. T. \& C. R. Moreira. 2003. Three new species of Hyphessobrycon (Characiformes: Characidae) from the upper rio Araguaia basin in Brazil. Neotropical Ichthyology, 1: 21-33.

Lima, F. C. T., L. R. Malabarba, P. A. Buckup, J. F. P. Silva, R. P. Vari, A. Harold, R. Benine, O. Oyakawa, C. S. Pavanelli, N. A. Menezes, C. A. S. Lucena, M. C. S. L. Malabarba, Z. M. S.
Lucena, R. E. Reis, F. Langeani, L. Casatti, V. A. Bertaco, C. Moreira \& P. H. F. Lucinda. 2003. Genera Incertae sedis in Characidae. Pp. 106-169. In: Reis, R. E., S. O. Kullander \& C. J. Ferraris-Jr. (Orgs.). Check List of the Freshwater Fishes of South and Central America. Porto Alegre, Edipucrs.

Lucena, C.A. S. 2003. New characid fish, Hyphessobrycon scutulus, from the rio Teles Pires drainage, upper rio Tapajós system (Ostariophysi: Characiformes: Characidae). Neotropical Ichthyology, 1: 93-96.

Malabarba, L. R. \& S. H. Weitzman. 2003. Description of a new genus with six new species from southern Brazil, Uruguay and Argentina, with a discussion of a putative characid clade (Teleostei: Characiformes: Characidae). Comunicações do Museu de Ciências e Tecnologia da Pontifícia Universidade Católica do Rio Grande do Sul, Série Zoologia, 16: 67-151.

Malabarba, L. R. 1998. Monophyly of the Cheirodontinae, Characters and major Clades (Ostariophysi: Characidae). Pp. 193-260. In: Malabarba, L. R., R. E. Reis, R. P. Vari, Z. M. S. Lucena \& C. A. S. Lucena (Eds.). Phylogeny and Classification of Neotropical Fishes. Porto Alegre, Edipucrs.

Malabarba, L. R., V. A. Bertaco, F. R. Carvalho \& T. O. Litz. 2012. Revalidation of the genus Ectrepopterus Fowler (Teleostei: Characiformes), with the redescription of its type species, $E$. uruguayensis. Zootaxa, 3204: 47-60.

Mirande, J. M. 2009. Weighted parsimony phylogeny of the family Characidae (Teleostei: Characiformes). Cladistics, 2009: 573613.

Mirande, J. M. 2010. Phylogeny of the family Characidae (Teleostei: Characiformes): from characters to taxonomy. Neotropical Ichthyology, 8: 385-568.

Oliveira, C., G. S. Avelino, K. T. Abe, T. C. Mariguela, R. C. Benine, G. Ortí, R. P. Vari \& R. M. C. Castro. 2011. Phylogenetic relationships within the speciose family Characidae (Teleostei: Ostariophysi: Characiformes) based on multilocus analysis and extensive ingroup sampling. BMC Evolutionary Biology, 11: 275.

Reis, R. E., S. O. Kullander \& C. J. Ferraris Jr. (Orgs.). 2003. Check List of the Freshwater Fishes of South and Central America. Porto Alegre, Edipucrs.

Taylor, W. R. \& G. C. Van Dyke. 1985. Revised procedures for staining and clearing small fishes and other vertebrates for bone and cartilage study. Cybium, 9: 107-119.

Villa-Verde, L., H. Lazzarotto \& S. M. Q. Lima. 2012. A new glanapterygine catfish of the genus Listrura (Siluriformes: Trichomycteridae) from southeastern Brazil, corroborated by morphological and molecular data. Neotropical Ichthyology, 10: 527-538.

Weitzman, S. H. 1962. The osteology of Brycon meeki, a generalized Characidae fish, with an osteological definition of the family. Stanford Ichthyogical Bulletin, 8: 1-77.

Weitzman, S. H. \& L. Palmer. 1997. A new species of Hyphessobrycon (Teleostei: Characidae) from the Neblina region of Venezuela and Brazil, with comments on the putative "rosy tetra clade". Ichthyological Exploration of Freshwaters, 7: 209242.

Zawadzki, C. H., J. L. O. Birindelli \& F. C. T. Lima. 2008. A new pale-spotted species of Hypostomus Lacépède (Siluriformes: Loricariidae) from the rio Tocantins and rio Xingu basins in central Brazil. Neotropical Ichthyology, 6: 395-402.

Submitted November 28, 2012 Accepted July 8, 2013 by Marcelo Britto Published September 30, 2013 